\title{
HUBUNGAN ANTARA NILAI YANG DIMILIKI STAKEHOLDER TERHADAP PENGEMBANGAN KEBIJAKAN EKOWISATA PADA TAMAN NASIONAL DI INDONESIA
}

\author{
Oleh : BHAYU RHAMA
}

\begin{abstract}
Abstrak
Taman Nasional adalah sebuah area yang diciptakan atau digunakan untuk melestarikan lingkungan alami pada sebuah pembangunan yang sedang berjalan di sekitarnya. Untuk mendukung keberhasilannya maka sejumlah isu manajerial yang muncul dalam pengelolaan taman nasional harus dikelola dengan baik. Model manajemen yang tepat untuk pengelolaan Taman Nasional adalah partisipatif dengan konsep ekowisata karena prinsip-prinsip ekowisata tersebut sejalan dengan konsep pembangunan berkelanjutan. Akan tetapi konsep ekowisata memerlukan keterlibatan stakeholder karena adanya pertimbangan yang lebih besar mengenai keanekaragaman, baik dari segi sosial, lingkungan, politik, budaya, maupun ekonomi. Kerangka strategis untuk menghasilkan kemitraan yang berhasil antar stakeholder dapat diwujudkan apabila pemerintah dapat menjelaskan dan memprediksi bagaimana stakeholder berperilaku untuk merespon dan memberikan pengaruh pada lingkungannya karena setiap stakeholder memiliki persepsi berbeda berdasarkan nilai kehidupan yang dianutnya, termasuk masalah ekowisata. Strategi utama yang mendukung pengembangan kebijakan ekowisata adalah dengan melihat pada nilai-nilai yang dianut oleh para aktor dan memprediksi bagaimana para aktor menggunakan nilai ini untuk membangun persepsi kognitif dan emosional mengenai pesan ekowisata yang dibangun bersama.
\end{abstract}

Kata-kata Kunci: Nilai; Ekowisata; Taman Nasional; Stakeholder

\section{Taman Nasional}

Taman Nasional adalah sebuah area yang diciptakan atau digunakan untuk melestarikan lingkungan alami pada sebuah pembangunan yang sedang berjalan di sekitarnya (Obenaus, 2005: 36). Taman nasional tidak harus berada di kawasan darat. Taman nasional di kawasan laut dapat pula dirumuskan dengan merujuk pada konservasi terumbu karang, rumput laut, situs arkeologis yang tenggelam, hutan xerofit, kepulauan lepas pantai, hutan bakau, spesies endemis yang menghuni kawasan laut, pantai, dan tebing (Liburd, 2006:164). Walau demikian, cara merencanakan dan mengatur taman nasional tergantung pada setiap peraturan, definisi, dan interpretasi yang dimiliki daerah tertentu. Sebagai contoh, di Malaysia, taman nasional diidentifikasikan sebagai area yang ditentukan untuk konservasi untuk menjaga kehidupan alam liar beserta habitatnya, melestarikan kondisi geologis atau fisiologis, digunakan sebagai tempat pendidikan dan penelitian tentang keanekaragaman hayati, menjaga keindahan alam, tempat dan monumen bersejarah, dan menyediakan tempat kepada masyarakat untuk apresiasi, kesenangan dan pendidikan pada keindahan alam, habitat 
alam liar, flora dan fauna, kondisi geologis dan fisiologis alam, dan sebagai tempat ataupun monumen bersejarah yang dimiliki Negara. (Tisen, 2004:32; Sarawak, 1998).

Sebagian dari fungsi taman nasional adalah fungsi yang mengandung intervensi manusia. Intervensi manusia ke dalam taman nasional menjamin agar fungsi penelitian, sains, pendidikan, budaya, pariwisata, dan rekreasi dapat berjalan. Walau begitu, dampak dari intervensi manusia ke dalam ekosistem alami akan menjadikan ekosistem tersebut tidak lagi terlalu alami. Kondisi ini memberikan efek ekologis maupun sosial. Efek ekologis mencakup hilangnya nutrisi dan tanah, sedimentasi/turbiditas air, perubahan jalur air, kerusakan akar, berkurangnya kesehatan pohon, menurunnya toleransi pada kekeringan, hilangnya vegetasi, terpaparnya tanah, pembentukan lumpur, meningkatnya debit air mengalir, percepatan laju erosi, dan fragmentasi habitat kehidupan liar (Marion dan Leung, 2001). Efek sosial yang terarah pada pengunjung sendiri berbentuk peningkatan pada kesulitan perjalanan, menurunnya estetika, isu keselamatan, dan hadirnya gangguan manusia (Liddle dan Greig- Smith, 1975).

Efek taman nasional terhadap lingkungan sosial-budaya masih merupakan sebuah bidang yang penuh perdebatan (Pelser, Redelinghuys, dan Velelo, 2012:57). Sebagian pihak memandang bahwa penyediaan manfaat untuk sosial dan manfaat untuk konservasi bersifat antagonis (Upton et al, 2008). Ketika kita berusaha untuk melakukan konservasi sebaik mungkin, maka hal ini akan berdampak buruk bagi masyarakat yang tinggal di sekitar kawasan konservasi atau di dalamnya. Pandangan ini berangkat dari asumsi dasar kalau konservasi berarti lingkungan yang sepenuhnya alamiah tanpa ada manusia di dalamnya (Pimbert dan Pretty, 1995:5).

Sebaliknya, ketika status Taman nasional dicabut atau disandingkan dengan status sebagai objek wisata, para wisatawan akan datang dan membawa modernisasi bagi masyarakat. Masyarakat akan mengenal uang dan akhirnya mengenal bagaimana menjadi kapitalis, yang kadangkala harus mengorbankan dan mengeksploitasi alam sebesar-besarnya untuk mendapatkan kesejahteraan individual. Pihak lain dapat berpendapat bahwa pembangunan dan konservasi dapat berjalan beriringan. Ada sebuah titik optimal dimana setiap stakeholder, termasuk alam itu sendiri, memperoleh manfaat maksimal dan kerugian minimum. Ini adalah sebuah solusi strategis yang membutuhkan kerjasama semua pihak dan inilah yang diusung oleh wacana pembangunan berkelanjutan.

\section{Manajemen Taman Nasional}

Literatur mengenai manajemen taman nasional banyak berangkat dari berbagai kasus yang dialami di berbagai negara. Sejumlah isu manajerial yang muncul dalam pengelolaan taman nasional antara lain:

\section{a. Mana yang Harus Diutamakan: Konservasi atau Ekonomi?}

Pembangunan akan berhenti ketika masyarakat asli tinggal di dalam taman nasional. Hal ini tidak akan menjadi masalah jika masyarakat asli memandang itu memang bukan masalah. Mereka akan mungkin memilih hidup sederhana asalkan tinggal di tanah sendiri daripada harus bermigrasi ke luar taman nasional untuk hidup yang lebih baik dalam standar kapitalisme. Keberhentian pembangunan mungkin tidak dapat begitu saja terjadi. Masyarakat lokal tetap terkena pengaruh ekonomi walau bagaimanapun jika tidak diisolasi. Para pengunjung dari kota besar cenderung mencari desa-desa yang terpencil untuk kebutuhan rekreasi (Lankford et al, 2004; Jacob dan Luloff, 1995). Tetapi karena mereka dikendalai secara ekonomi, maka keuntungan dari kunjungan tersebut tidak sampai pada mereka. Hal ini 
menurut Fennell $(2008,166)$, tergantung pada bagaimana orientasi masyarakat lokal, berorientasi pada kepuasan pengunjung atau keuntungan.

Pemerintah sendiri dilarang untuk mengusir masyarakat asli dari suatu taman nasional. Zaire Resolution on the Protection of Traditional Ways of Life (IUCN, 1975) melarang hal tersebut dilakukan. Lebih jauh, kebutuhan masyarakat asli harus diperhatikan dalam manajemen taman nasional (Poirier dan Ostergren, 2002:341). Kebijakan ini akan terlihat berkonflik dengan upaya pemerataan pembangunan atau pengentasan kemiskinan yang berskala menyeluruh yang dilakukan oleh negara.

Aspek ekonomi yang harus diperhitungkan bukan saja aspek ekonomi dari masyarakat asli, namun dari taman nasional itu sendiri. Perawatan taman nasional membutuhkan biaya dan biaya ini hadir dari pemerintah. Walau begitu, dana dari pemerintah dapat tidak mencukupi, apalagi bagi negara berkembang. Karenanya, pengelola taman nasional, baik legal atau tidak, dapat mengambil dana dari sumber lain, yang dapat mengorbankan sisi konservasi dari taman nasional.

\section{b. Siapa yang Mengelola}

Setidaknya terdapat dua stakeholder taman nasional: pemerintah dan masyarakat asli. Walaupun dua stakeholder ini telah terlihat sangat minim, tapi sesungguhnya terdapat faksi- faksi di dalam masyarakat asli yang berbeda pendapat. Bahkan ketika faksi-faksi di dalam masyarakat asli telah sependapat, terdapat isu kepercayaan terhadap pemerintah yang harus diselesaikan (Chi, 2007:17). Hal ini membuat upaya manajemen bersama akan menjadi sulit. Dalam pemerintahan otoriter, seperti Indonesia di masa lalu, pemerintah dapat dengan tegas dalam mengelola taman nasional tanpa perlu kerjasama dari masyarakat asli.

Pimbert dan Pretty (1995) membedakan dengan tajam sejumlah aspek yang dimiliki oleh manajemen taman nasional berbasis ilmiah dan berbasis holistik. Tabel 1.1 menunjukkan perbedaan tersebut. Dapat dilihat bahwa kedua model manajemen tersebut mencerminkan perbedaan antara manajemen dalam latar otoritarianisme dan manajemen dalam latar demokrasi.

Tabel 1.1 Perbedaan Manajemen Berbasis Ilmiah (Cetak Biru) dan Manajemen Berbasis Holistik (Proses)

\begin{tabular}{|c|c|c|}
\hline & Model Cetak Biru & Model Proses \\
\hline \begin{tabular}{|l|} 
Titik \\
keberangkatan \\
\end{tabular} & $\begin{array}{l}\text { Keanekaragaman hayati, estetika, } \\
\text { dan potensi nilai komersilnya }\end{array}$ & $\begin{array}{l}\text { Keanekaragaman nilai manusia dan } \\
\text { alam }\end{array}$ \\
\hline $\begin{array}{l}\text { Lokus pembuatan } \\
\text { keputusan }\end{array}$ & $\begin{array}{l}\text { Sentralistik. Gagasan datang dari } \\
\text { ibukota }\end{array}$ & $\begin{array}{l}\text { Desentralistik. Gagasan datang dari } \\
\text { desa }\end{array}$ \\
\hline Desain & Statis, berdasarkan para ilmuan & Berevolusi, melibatkan masyarakat \\
\hline $\begin{array}{l}\text { Metode } \\
\text { aturan }\end{array}$ & Standar, universal, dan tetap & $\begin{array}{lll}\text { Beranekaragam, lokal, } & \text { banyak } \\
\text { pilihan } & & \\
\end{array}$ \\
\hline $\begin{array}{l}\text { Fokus } \\
\text { manajemen }\end{array}$ & $\begin{array}{l}\text { Menghabiskan anggaran, } \\
\text { menyelesaikan proyek tepat waktu }\end{array}$ & Perbaikan dan kinerja berkelanjutan \\
\hline Evalua & Eksternal, berkala & Internal, berkelanjutan \\
\hline $\begin{array}{l}\text { Hubungan } \\
\text { dengan } \\
\text { masyarakat }\end{array}$ & $\begin{array}{lr}\text { Mengendalikan, } & \begin{array}{r}\text { mengatur, } \\
\text { memotivasi, } \\
\text { mendorong, } \\
\text { menciptakan }\end{array} \\
\text { ketergantungan. }\end{array}$ & $\begin{array}{lr}\text { Memungkinkan, } & \text { mendukung, } \\
\text { memberdayakan. } & \text { Masyarakat } \\
\text { dipandang sebagai pelaku } & \end{array}$ \\
\hline
\end{tabular}




\begin{tabular}{|c|c|c|}
\hline & $\begin{array}{l}\text { Masyarakat dipandang sebagai } \\
\text { penerima manfaat }\end{array}$ & \\
\hline Keluaran & $\begin{array}{l}\text { Keanekaragaman } \quad \begin{array}{l}\text { konservasi, } \\
\text { keseragaman }\end{array} \\
\text { pemberdayaan profesional }\end{array}$ & $\begin{array}{l}\text { Keanekaragaman sebagai prinsip } \\
\text { produksi dan konservasi, } \\
\text { pemberdayaan masyarakat desa }\end{array}$ \\
\hline $\begin{array}{l}\text { Berasosiasi } \\
\text { dengan }\end{array}$ & Profesionalisme normal & Profesionalisme baru \\
\hline Kesalahan & Dikubur & Dijadikan pembelajaran \\
\hline Komunikasi & $\begin{array}{l}\text { Vertikal, perintah turun, laporan } \\
\text { naik }\end{array}$ & $\begin{array}{l}\text { Lateral, belajar dan berbagi } \\
\text { pengalaman bersama }\end{array}$ \\
\hline Asumsi analitis & $\begin{array}{l}\text { Reduksionis dengan bias sains } \\
\text { alam }\end{array}$ & Sistem dan holistik \\
\hline $\begin{array}{l}\text { Sumberdaya } \\
\text { utama }\end{array}$ & $\begin{array}{l}\text { Dana dari pusat dan sumberdaya } \\
\text { manusia terlatih dan terdidik }\end{array}$ & Masyarakat lokal dan aset mereka \\
\hline Langkah awal & $\begin{array}{l}\begin{array}{l}\text { Pengumpulan data } \\
\text { perencanaan }\end{array} \\
\text { dan }\end{array}$ & Kesadaran dan tindakan \\
\hline Kata kunci & Perencanaan strategis & Partisipasi \\
\hline \begin{tabular}{|l|} 
Penyusun \\
prioritas
\end{tabular} & Profesional di bidang konservasi & $\begin{array}{llll}\begin{array}{l}\text { Masyarakat lokal dan profesional } \\
\text { bekerja sama }\end{array} & & \\
\end{array}$ \\
\hline $\begin{array}{l}\text { Strategi dan } \\
\text { konteks intervensi }\end{array}$ & $\begin{array}{l}\text { Profesional tahu apa yang mereka } \\
\text { inginkan, mereka membuat } \\
\text { rencana penelitian atau desain } \\
\text { proyek, informasi dan hasil } \\
\text { diperoleh dari situasi terkontrol, } \\
\text { konteks bersifat independen dan } \\
\text { terkendali }\end{array}$ & $\begin{array}{l}\text { Profesional memang tahu apa yang } \\
\text { mereka inginkan tetapi tidak tahu } \\
\text { bagaimana hasilnya. Ini menjadi proses } \\
\text { belajar terbuka dan pembelajaran hadir } \\
\text { lewat interaksi dengan penduduk lokal. } \\
\text { Konteks menjadi penting dan mendasar }\end{array}$ \\
\hline $\begin{array}{l}\text { Hubungan antara } \\
\text { semua aktor dalam } \\
\text { proses }\end{array}$ & $\begin{array}{l}\text { Profesional mengendalikan dan } \\
\text { memotivasi klien dari jarak jauh; } \\
\text { mereka tidak percaya pada } \\
\text { masyarakat lokal }\end{array}$ & $\begin{array}{l}\text { Profesional memberdayakan } \\
\text { masyarakat lokal lewat dialog, } \\
\text { membangun kepercayaan, melakukan } \\
\text { negosiasi dan analisis bersama, semua } \\
\text { pihak dilibatkan }\end{array}$ \\
\hline $\begin{array}{l}\text { Teknologi atau } \\
\text { pelayanan } \\
\text { konservasi }\end{array}$ & 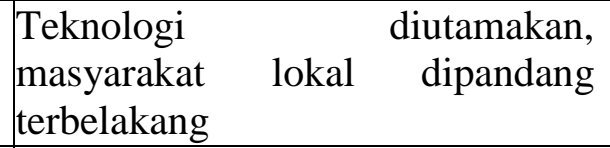 & $\begin{array}{l}\text { Masyarakat diutamakan, teknologi } \\
\text { dipandang milik bersama }\end{array}$ \\
\hline $\begin{array}{l}\text { Pengembangan } \\
\text { karir }\end{array}$ & $\begin{array}{l}\text { Bersifat vertikal dan semakin } \\
\text { tinggi jabatan, semakin jauh dari } \\
\text { lapangan }\end{array}$ & $\begin{array}{l}\text { Bersifat horizontal dan semakin tinggi } \\
\text { jabatan, semakin dekat dengan } \\
\text { masyarakat }\end{array}$ \\
\hline Mode kerja & Satu disiplin, bekerja sendiri & $\begin{array}{l}\text { Multi disiplin, bekerja dalam } \\
\text { kelompok }\end{array}$ \\
\hline $\begin{array}{ll}\text { Asumsi tentang } \\
\text { realitas }\end{array}$ & Singular, tampak & Jamak dan dikonstruksi sosial \\
\hline $\begin{array}{l}\text { Ilmu dan metode } \\
\text { konservasi }\end{array}$ & $\begin{array}{l}\text { Positivisme atau post- positivisme; } \\
\text { sains alam, mencari hubungan } \\
\text { sebab akibat, kategori dan persepsi } \\
\text { pakar penting }\end{array}$ & $\begin{array}{l}\text { Konstruksionisme, holistik (sains alam } \\
\text { dan sosial), mencari kesepakatan, } \\
\text { kategori dan persepsi masyarakat lokal } \\
\text { penting }\end{array}$ \\
\hline
\end{tabular}

Sumber: Pimbert dan Pretty (1995:20-21; 36-37); Pretty dan Chambers (1993)

Dari tabel di atas, terlihat bahwa paradigma baru lebih masuk akal dan lebih memenuhi 
kebutuhan masa kini. Paradigma baru yang partisipatif merupakan jawaban atas kompleksitas masalah yang semakin besar, seiring dengan semakin besarnya kesadaran bahwa manajemen taman nasional tidak semata masalah manajemen benda mati. Pimbert dan Pretty (1995:47) sadar bahwa paradigma partisipatif adalah paradigma yang sulit untuk dijangkau dan dilaksanakan, apalagi di negara berkembang. Masyarakat lokal telah sampai pada titik dimana mereka dipandang sebagai pencuri sumberdaya alam di tanah mereka sendiri, hanya untuk mencari makanan, bahan bakar, pemenuhan kebutuhan kultural, kesehatan, dan naungan (Pimbert dan Pretty, 1995:48). Sementara itu, pemerintah dipandang sebagai pihak yang tidak dapat diandalkan dalam menjaga kelangsungan hidup alam dan mereka.

Baik paradigma profesional maupun partisipatif merupakan dua ekstrim yang berbeda tajam. Pada kenyataannya, manajemen taman nasional akan selalu berada dalam dua titik ekstrim tersebut. Gambaran yang lebih realistis adalah sintesis antara kedua paradigma. Sintesis ini dapat dilihat dari aspek kata kunci yang melibatkan baik perencanaan strategis dari paradigma profesional maupun partisipasi dari paradigma partisipatif. Hasilnya adalah strategic integrated sustainable management (SISM). Kerangka SISM dapat dirumuskan sebagai berikut:

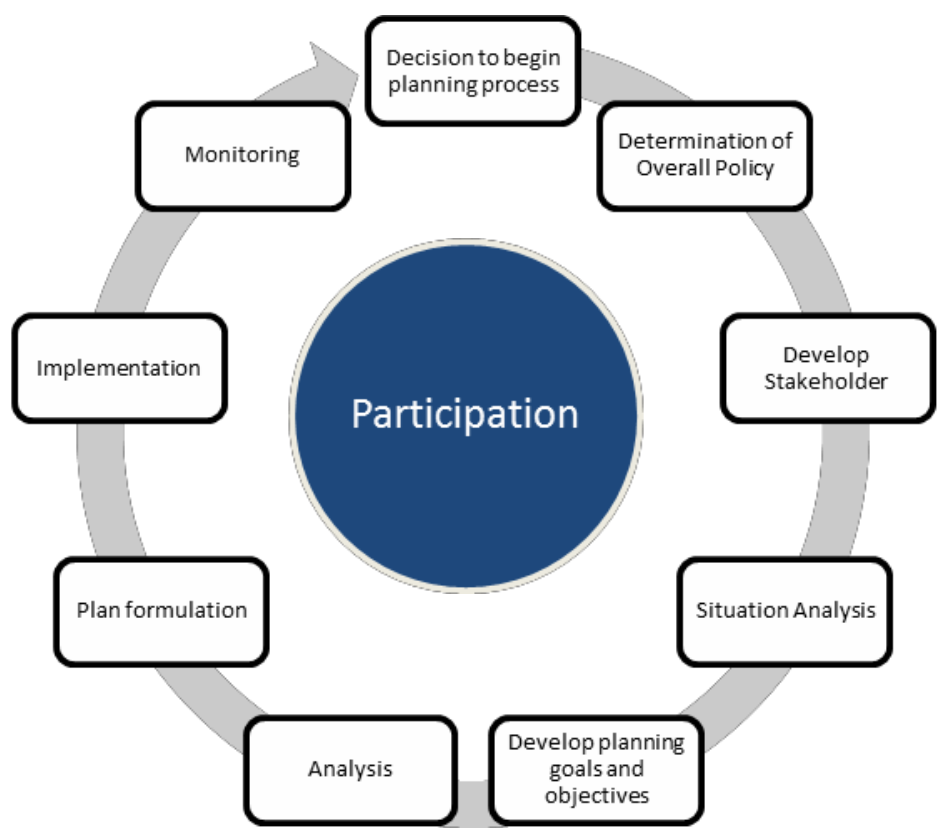

Sumber: Tantisirak, 2007:36

Dalam gambar di atas, idealnya prinsip partisipasi diterapkan pada semua tahapan. Walau begitu, besar kemungkinan kalau hanya ada satu pihak yang memulai siklus yang kemudian menambah jumlah partisipan dalam tahapan develop stakeholder.

\section{c. Apa yang dikelola}

Taman nasional merupakan sebuah sistem yang sangat luas dan mengandung banyak komponen yang saling berinteraksi. Setiap pengelola taman nasional harus berhadapan dengan tiga pilihan indikator untuk diutamakan: (a) indikator yang mudah diawasi, (b) indikator yang bernilai ekologis, dan (c) indikator yang bernilai bagi stakeholder (Timko dan Innes, 2009:10). 
Dalam konteks partisipatif, pendekatan yang dapat dilakukan untuk mengetahui apa yang harus diprioritaskan dapat menggunakan analisis SWOT (Strength, Weakness, Opportunity, Threat) yang dikombinasikan dengan AHP (Analytical Hierarchy Process). Pendekatan SWOT menilai faktor-faktor yang menentukan keberhasilan suatu langkah (Weihrich, 1992) sementara AHP menilai kekuatan dari faktor-faktor dari sudut pandang stakeholder utama: pemerintah, masyarakat lokal, dan lembaga lingkungan hidup (Masozera et al, 2006:207).

\section{d. Bagaimana Mengelola}

Ketika isu siapa yang mengelola dan apa yang harus diutamakan telah mencapai resolusi, bagaimana taman nasional dikelola tidak akan sulit secara teoritis. Ada dua tipe umum manajemen taman nasional yang dapat digunakan: manajemen standar dan manajemen adaptif.

Manajemen standar berlaku bagi aspek-aspek taman nasional yang dapat diprediksi dengan mudah. Dalam pengelolaan jalan misalnya, telah terdapat banyak panduan yang dapat digunakan (misalnya Cole, 1983). Jalan merupakan hal penting karena kepuasan pengunjung didasarkan pada kondisi jalan, kemampuan pengunjung lainnya, kerusakan yang disebabkan oleh penggunaan berlebih, dan sistem reservasi jalan (Lankford et al, 2004:382).

Manajemen adaptif berhadapan dengan isu lingkungan yang tidak pasti (Markel dan Clark, 2012; Prato, 2006; Ludwig, Hillborn, dan Waters, 1993). Sistem ini diarahkan pada aspek seperti perubahan iklim, wabah penyakit, perilaku spesies, dan siklus alamiah yang terganggu. Langkah manajemen adaptif bersifat kontekstual dimana manajer harus selalu siap untuk menghadapi perubahan tak terduga di lapangan. Sistem manajemen seperti ini akan sulit berkembang dalam kondisi peraturan yang terlalu ketat dan ketidakberanian manajer untuk mengambil risiko.

\section{Manajemen Taman Nasional di Indonesia}

Indonesia adalah sebuah negara yang berada di lintasan garis khatulistiwa. Hingga sekarang, masih banyak ditemukan masyarakat yang hidup dengan pola berburu mengumpul di sejumlah pulau besar di Indonesia. Kondisi ini membuat masyarakat Indonesia lebih cenderung fundamentalis-ekosentris dengan memandang kesatuan dengan alam. Pandangan ini cenderung resistif terhadap wacana taman nasional yang lebih ke arah konservasionis- antroposentris. Hal ini menjelaskan mengapa wacana taman nasional lama baru muncul di Indonesia.

Dalam era ini, manajemen taman nasional masih diarahkan pada kebijakan keanekaragaman hayati. Taman nasional, berdasarkan Undang-Undang No. 5 tahun 1990 tentang Konservasi dan Sumber Daya Alam dan Ekosistemnya didedifiniskan sebagai sebuah area konservasi alam yang memiliki ekosistem alami, yang diatur berdasarkan zonasi berdasarkan kepentingannya untuk penelitian, ilmu pengetahuan, pendidikan, budaya, wisata dan rekreasi alam. Taman nasional kemudian telah diatur lewat sistem zonasi. Zona wajib yang mesti ada adalah zona inti yang mutlak harus digunakan sepenuhnya untuk konservasi. Selain zona inti, variasi zona dapat mencakup zona rimba, zona pemanfaatan penelitian dan pengembangan, zona pemanfaatan tradisional, zona penyangga, zona budidaya, zona rehabilitasi, dan zona pemanfaatan permukiman tradisional dan lainnya. Sistem zonasi ini sebenarnya menggemakan World Network of Biosphere Reserves tahun 1970an yang 
membagi daerah pelestarian biosfer ke dalam sejumlah zona (Vernhes dan Bridgewater, 2008:28). Gambar 1.1 menunjukkan pembagian zona yang didesignasikan oleh World Network of Biosphere Reserves.

\section{Gambar 1.1 Sistem Zonasi Biosfer}

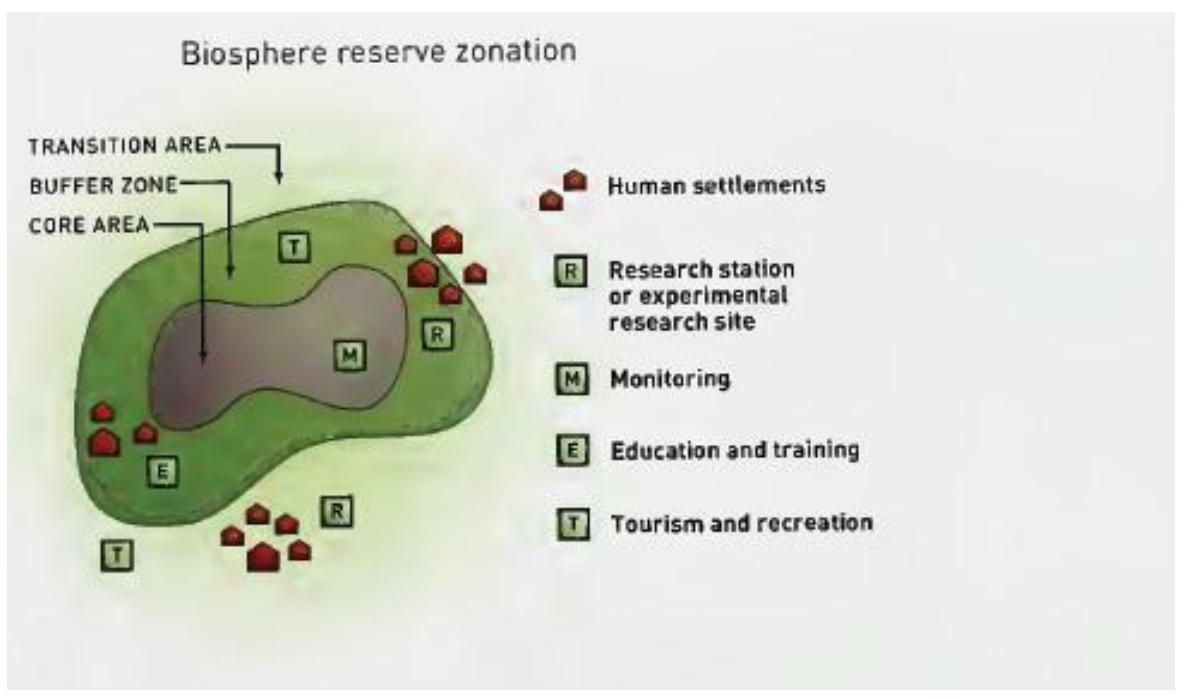

Sumber: Vernhes dan Bridgewater, 2008:29

Ditambahkan juga di dalam era ini, sejumlah langkah partisipatif memang telah dijalankan dan berhasil seperti di Taman Nasional Wasur, Papua, (Pimbert dan Pretty, 1995:39), Pegunungan Lorenz, Papua (Deddy, 2006:95), Taman Nasional Kayan Mentarang, Kalimantan (Deddy, 2006:95), dan Bunaken di Sulawesi (Sembiring, 2005). Kebijakan yang menaungi manajemen taman nasional yang muncul di era ini adalah Peraturan Pemerintah No 68 tahun 1998 tentang Konservasi dan Daerah Terlindungi dan serta Keputusan Menteri Kehutanan No 56 tahun 2006 tentang Zonasi dalam Taman Nasional Keputusan Menteri Kehutanan No 129/Kpts/DJ-VI/1996 tentang Pedoman Penetapan Zonasi Taman Nasional (Eghenter, 2006:168).

Dalam Peraturan Pemerintah No 68 tahun 1998, taman nasional ditetapkan setidak- tidaknya memiliki tiga zona yaitu zona inti, zona rimba, dan zona pemanfaatan. Fungsi zona inti adalah sebagai pelindung ekosistem serta keanekaragaman hayati yang peka terhadap gangguan dan perubahan, sumber plasma nutfah dan jenis tumbuhan serta satwa liar, kepentingan pendidikan, penelitian, dan pengembangan, dan penunjang zona rimba dan pemanfaatan. Fungsi zona rimba mencakup fungsi konservasi, penelitian, pendidikan, pengembangan, wisata terbatas, habitat satwa migran, dan penunjang zona pemanfaatan dan pendukung zona inti. Fungsi zona pemanfaatan pariwisata, jasa lingkungan, pendidikan, pengembangan, penelitian, dan pendukung zona inti dan rimba.

Sungguhpun demikian, warisan dari masa lalu menyisakan pemanfaatan lahan berskala besar terdiri dari pemanfaatan ekonomis dan konservasi dalam proporsi yang relatif tidak sebanding. Indonesia memiliki 50 taman nasional dengan luas total taman nasional mencapai 16,4 juta hektar (ditambah 527 hutan konservasi lainnya seperti cagar alam dan suaka margasatwa menjadi seluas 48 juta hektar), luas ini masih tergolong kecil dibandingkan 75 juta hektar tanaman industri (60 juta hektar untuk kayu dan 15 juta hektar untuk tanaman perkebunan) (Young, 2012; Fay, Sirait, dan Kusworo, 2000). 
Tabel 1.1 Taman Nasional di Indonesia

\begin{tabular}{|c|c|c|c|c|c|}
\hline & Nama & Lokasi & Wisata & Berdiri & $\begin{array}{r}\text { Luas saat ini } \\
\text { (ha) }\end{array}$ \\
\hline 1 & Gunung Gede Pangrango & Jawa & $\mathrm{Ya}$ & 1980 & $15,000.00$ \\
\hline 2 & Baluran & Jawa & ya & 1980 & $25,000.00$ \\
\hline 3 & Ujung Kulon & Jawa & $\mathrm{Ya}$ & 1980 & $122,956.00$ \\
\hline 4 & Gunung Leuser & Sumatera & Tidak & 1980 & $1,094,692.00$ \\
\hline 5 & Kerinci Seblat & Sumatera & $\mathrm{Ya}$ & 1982 & $1,375,349.87$ \\
\hline 6 & Way Kambas & Sumatera & $\mathrm{Ya}$ & 1982 & $125,621.30$ \\
\hline 7 & Bromo Tengger Semeru & Jawa & $\mathrm{Ya}$ & 1982 & $50,276.20$ \\
\hline 8 & Laut Kepulauan Seribu & Jawa & $\mathrm{Ya}$ & 1982 & $107,489.00$ \\
\hline 9 & Meru Betiri & Jawa & $\mathrm{Ya}$ & 1982 & $58,000.00$ \\
\hline 10 & Kutai & Kalimantan & $\mathrm{Ya}$ & 1982 & $198,629.00$ \\
\hline 11 & Tanjung Puting & Kalimantan & $\mathrm{Ya}$ & 1982 & $415,040.00$ \\
\hline 12 & Lore Lindu & Sulawesi & $\mathrm{Ya}$ & 1982 & $217,991.18$ \\
\hline 13 & Bogani Nani Wartabone & Sulawesi & Tidak & 1982 & $287,115.00$ \\
\hline 14 & Bukit Barisan Selatan & Sumatera & $\mathrm{Ya}$ & 1982 & $365,000.00$ \\
\hline 15 & Rawa Aopa Watumohai & Sulawesi & Tidak & 1989 & $105,194.00$ \\
\hline 16 & Gunung Palung & Kalimantan & Tidak & 1990 & $90,000.00$ \\
\hline 17 & Gunung Rinjani & $\begin{array}{l}\text { Nusa } \\
\text { Tenggara }\end{array}$ & $\mathrm{Ya}$ & 1990 & $40,000.00$ \\
\hline 18 & Komodo & $\begin{array}{l}\text { Nusa } \\
\text { Tenggara }\end{array}$ & Ya & 1990 & $173,300.00$ \\
\hline 19 & Teluk Cendrawasih & Papua & Tidak & 1990 & $1,453,500.00$ \\
\hline 20 & Wasur & Papua & Tidak & 1990 & $413,810.00$ \\
\hline 21 & Bunaken & Sulawesi & Tidak & 1991 & $89,065.00$ \\
\hline 22 & Berbak & Sumatera & ya & 1992 & $162,700.00$ \\
\hline 23 & Alas Purwo & Jawa & ya & 1992 & $43,420.00$ \\
\hline 24 & Gunung Halimun & Jawa & $\mathrm{Ya}$ & 1992 & $40,000.00$ \\
\hline 25 & Bukit Baka - Bukit Raya & Kalimantan & $\mathrm{Ya}$ & 1992 & $181,090.00$ \\
\hline 26 & Kelimutu & $\begin{array}{l}\text { Nusa } \\
\text { Tenggara }\end{array}$ & $\mathrm{Ya}$ & 1992 & $5,356.50$ \\
\hline 27 & Taka Bonerate & Sulawesi & $\mathrm{Ya}$ & 1992 & $530,765.00$ \\
\hline 28 & Siberut & Sumatera & Tidak & 1993 & $190,500.00$ \\
\hline 29 & Bukit Tigapuluh & Sumatera & Tidak & 1995 & $127,000.00$ \\
\hline 30 & Bali Barat & $\begin{array}{l}\text { Nusa } \\
\text { Tenggara }\end{array}$ & ya & 1995 & $19,002.89$ \\
\hline 31 & Betung Kerihun & Kalimantan & $\mathrm{Ya}$ & 1995 & $800,000.00$ \\
\hline 32 & Kayan Mentarang & Kalimantan & $\mathrm{Ya}$ & 1996 & $1,360,500.00$ \\
\hline
\end{tabular}




\begin{tabular}{|l|l|l|l|l|r|}
33 & Wakatobi & Sulawesi & Ya & 1996 & $1,390,000.00$ \\
\hline 34 & Karimunjawa & Jawa & Ya & 1997 & $110,117.30$ \\
\hline 35 & Manusela & Maluku & Ya & 1997 & $189,000.00$ \\
\hline 36 & Lorentz (Cyclops) & Papua & Tidak & 1997 & $2,450,000.00$ \\
\hline 37 & Laiwangi Wanggameti & $\begin{array}{l}\text { Nusa } \\
\text { Tenggara }\end{array}$ & Tidak & 1998 & $47,014.00$ \\
\hline 38 & Manupeu Tanah Daru & Nusa & Ya & 1998 & $87,984.09$ \\
\hline 39 & Danau Sentarum & Kalimantan & Ya & 1999 & $132,000.00$ \\
\hline 40 & Bukit Duabelas & Sumatera & Ya & 2000 & $60,500.00$ \\
\hline 41 & Sembilang & Sumatera & Tidak & 2001 & $205,750.00$ \\
\hline 42 & Batang Gadis & Sumatera & ya & 2004 & $144,233.00$ \\
\hline 43 & Tesso Nilo & Sumatera & Ya & 2004 & $38,576.00$ \\
\hline 44 & Gunung Ciremai & Jawa & Ya & 2004 & $15,500.00$ \\
\hline 45 & Gunung Merbabu & Jawa & Ya & 2004 & $5,725.00$ \\
\hline 46 & Bantimurung Bulusaraung & Sulawesi & ya & 2004 & $10,282.65$ \\
\hline 47 & Kepulauan Togean & Sulawesi & Tidak & 2004 & $362,605.00$ \\
\hline 48 & Aketajawe Lolobata & Maluku & Tidak & 2004 & $167,300.00$ \\
\hline 49 & Gunung Merapi & Jawa & Tidak & 2004 & $6,410.00$ \\
\hline 50 & Sebangau & Kalimantan & Ya & 2004 & $568,700.00$ \\
\hline & Total & & & & $16,275,059.98$ \\
\hline
\end{tabular}

Sumber: Dit PJLK, 2011 untuk data ekowisata dan http://www.dephut.go.id/uploads/INFORMASI/TN\%20INDO-ENGLISH/tn_index.htm untuk data luas dan tahun berdiri

Keduanya saling berkontestansi akibat tidak jelasnya perizinan, definisi hutan, dan kewenangan (Young, 2012). Masalah perizinan dan kewenangan muncul karena pergeseran dalam sistem pemerintahan dari sentralistik menjadi desentralisasi (Piskorskaya et al, 2012:118). Pergeseran ini mendorong pemerintah lokal bertanggungjawab untuk mengatur sumber daya alam, termasuklah taman nasional.

Studi oleh Beukering, Cesar, dan Janssen (2003) di Taman Nasional Leuser, Sumatera, menunjukkan kalau bahkan dari perspektif ekonomi sekalipun, upaya konservasi lebih unggul daripada upaya deforestrasi dan penggunaan selektif, hanya saja manfaat yang diperoleh lebih tersebar. Dalam konteks deforestrasi, hanya perusahaan kayu, pemerintah daerah, dan sebagian anggota masyarakat lokal yang diuntungkan secara ekonomi. Keuntungan ini datang dari pendapatan kayu. Dalam konteks konservasi, perusahaan kayu tidak menjadi pihak yang diuntungkan, tetapi jumlah pihak yang diuntungkan menjadi sangat banyak, mulai dari anggota masyarakat lokal, pemerintah daerah, pemerintah pusat, dan masyarakat internasional. Keuntungan ini datang dari pasokan air, pariwisata, pencegahan banjir, dan pertanian.

Dalam konteks Indonesia, Eghenter (2006:174) menyarankan langkah-langkah partisipatif dalam manajemen taman nasional antara lain:

1) Pengakuan lahan adat secara resmi dan pembangunan dewan adat yang berperan sebagai pengelola taman nasional 
2) Menerima zona inti de facto sebagai daerah yang terlalu jauh dari permukiman dan tidak dieksploitasi oleh masyarakat lokal namun tetap mempertahankan fungsi ekologis wilayah konservasi

3) Membentuk lembaga atau forum antar adat yang mengatur aktivitas manajerial dan masalah lingkungan yang sering melintasi batas adat

4) Melestarikan regulasi yang dikembangkan secara lokal mengenai penggunaan hasil hutan yang menjamin keberlanjutan

5) Mengakui wilayah yang definitif dan tepat dalam membedakan masyarakat adat dan bukan adat

6) Mengakui kalau Taman nasional yang dibangun dalam wilayah masyarakat asli paling baik diatur dan dilindungi sebagai hutan adat

Manajemen partisipatif yang melibatkan beberapa negara juga telah dilakukan. Indonesia bekerjasama dengan Malaysia dan Philipina mengelola kawasan perairan eko- region Sulawesi. Bersama Malaysia, Indonesia mengelola Taman Nasional Betung Kerihun, Lanjak Entimau, dan Kayan Mentarang. Selain itu, kerjasama dengan Malaysia dan Brunei dilakukan untuk kawasan Jantung Kalimantan seluas 22 juta hektar taman nasional lintas negara yang saling terkonteksi. Di Papua, Indonesia bekerjasama dengan Papua Nugini untuk pengelolaan Taman Nasional Wasur dan Tonda. Di Taman Nasional Bukit Tiga Puluh, Indonesia bekerjasama dengan Norwegia (Ministry of Environment, 2006).

Model manajemen lainnya adalah ekowisata. Dalam model ini, taman nasional dibuka untuk kegiatan pariwisata, namun dengan batasan-batasan yang ketat. Taman Nasional Gunung Gede Pangrango, Jawa, merupakan contoh yang positif mengenai strategi ekowisata. Pendapatan yang diperoleh taman nasional tidak terlalu besar, namun ini telah cukup baik untuk tingkatan taman nasional dimana sejumlah keterbatasan harus dibuat dengan tetap memperhatikan kebutuhan masyarakat lokal untuk memperoleh kesejahteraan dan kebutuhan wisatawan untuk memperoleh kepuasan (Nuva et al, 2009).

\section{Konsep Ekowisata}

Ekowisata dapat didefinisi secara luas atau secara ketat. Secara luas, ekowisata tidak lain adalah pariwisata berbasis alam (Barker, 2009:51). Dalam definisi yang paling ketat, ekowisata adalah - perjalanan menuju wilayah yang rapuh, asli, dan biasanya terlindungi yang diharapkan memberikan dampak minimum dan berskala kecil, dan mendidik pengunjung, menyediakan dana untuk konservasi, memberikan manfaat ekonomi langsung dan pemberdayaan politik masyarakat lokal, serta memberikan penghargaan terhadap berbagai budaya dan hak asasi manusiall (John dan Pang, 2002:4). Definisi yang lebih renggang mencakup definisi dari International Ecotourism Society (TIES) sebagai - perjalanan bertanggungjawab ke daerah alami yang melestarikan lingkungan dan meningkatkan kesejahteraan masyarakat lokall (Chambliss, Slotkin, dan Vamosi, 2008; TIES, 2007). Dalam disertasi ini, definisi yang diadopsi adalah definisi yang paling ketat mengenai ekowisata.

Konsep ekowisata berkembang sebagai bentuk upaya melawan efek negatif dari pariwisata massal yang terus berkembang dan memberikan efek buruk pada lingkungan hidup (McGahey, 2012:75). Konsep ini hadir setidaknya di pertengahan 1960-an ketika Hetzer (1965 dalam Blamey, 2001:5) mengemukakan empat pilar pariwisata yang bertanggung jawab, mencakup minimalisasi dampak lingkungan, memaksimalkan manfaat bagi penduduk lokal, menghargai negara sumber, dan memaksimalkan kepuasan wisatawan. Walau begitu, 
Hetzer sendiri mendefinisikan ekowisata sebagai — bentuk pariwisata yang berdasarkan pada sumberdaya alam dan arkeologis seperti gua, lokasi fosil, dan situs arkeologill (Higham, 2007:2). Walau begitu, konsep awal ini telah menempatkan perlindungan alam sebagai fungsi utama di atas fungsi menghasilkan uang. Fungsi pendidikan, mutu pariwisata, dan partisipasi lokal baru datang kemudian (Ross dan Wall, 1999:125).

Prinsip-prinsip ekowisata tersebut sejalan dengan konsep pembangunan berkelanjutan sehingga dapat digunakan untuk memandu pengembangan dan manajemen wisata berbasis alam dan berlaku untuk masyarakat lokal, wisatawan, dan pengelola (Dawson, 2008; UNESCAP, 1995). Terdapat beberapa versi prinsip ekowisata (Fennell, 2003; Diamantis, 1999; Sirakaya, Sasidharan, dan Sonmez, 1999). Menurut Fennell (2003), prinsip ini mencakup (1) keberminatan pada alam, (2) kontribusi pada konservasi, (3) kebertopangan pada taman dan daerah terlindungi, (4) manfaat jangka panjang atau manfaat bagi masyarakat lokal, (5) pendidikan dan studi, (6) berdampak rendah dan non konsumtif, (7) berkelanjutan,

(8) manajemen bertanggungjawab dan etis, (9) menikmati dan mengapresiasi budaya, dan

(10) berskala kecil dan bertualang.

Dengan melihat prinsip tersebut maka ekowisata akan berhubungan dengan nilai-nilai lingkungan yang dianut oleh stakehorlders (Zografos dan Allcroft, 2007:46). Karena nilai lingkungan dari stakeholders dapat berbeda, maka tidak mengherankan jika pada akhirnya, seringkali konsep ekowisata dipahami berbeda dan disesuaikan dengan tujuan masing-masing stakeholder (Dam, 2013; FEWMD, 2009). Ada dua cara untuk menghadapi permasalahan ini. Pertama adalah membangun satu definisi bersama antar stakeholder (WTO, 2002:17), atau menggunakan satu perspektif saja lalu memaksakan perspektif tersebut. Untuk mempermudah penyelesaian masalah, prinsip ekowisata dapat dibangun hanya dari perspektif pemerintah atau masyarakat. Dari upaya ini lahirlah konsep ekowisata berbasis masyarakat (Scheyvens, 1999:246). Ekowisata berbasis masyarakat didefinisikan sebagai —bentuk ekowisata dimana masyarakat lokal memiliki kendali mendasar pada, dan terlibat dalam, pengembangan dan manajemen, serta memperoleh keuntungan dalam proporsi yang besar dalam masyarakat itu sendirill (Miller, 2008:12; Denman, 2001:4).

Implementasi prinsip-prinsip ekowisata termasuk sulit dilakukan. Banyak proyek ekowisata akhirnya gagal menghadapi masalah mendasar dan tidak menghasilkan manfaat yang diharapkan dari ekowisata (Buchsbaum, 2004:1). Beberapa efek negatif dari ekowisata antara lain: (1) masyarakat lokal dipasarkan sebagai objek, (2) ketidaksetaraan sosial, (3) meningkatkan akses pada obat-obatan dan alkohol, (4) pertumbuhan populasi tidak terkendali, (5) kegagalan menyediakan manfaat ekonomi, (6) masyarakat lokal terbatas dalam membuat keputusan, (7) pencemaran limbah dan suara, (8) gangguan habitat, (9) degradasi hutan karena jalan masuk, (10) urbanisasi yang mengikis budaya dan nilai, dan (11) bocornya pendapatan ekowisata ke negara maju.

\section{Ekowisata di Indonesia}

Ekowisata di Indonesia baru muncul pada tahun 1995 dari sebuah seminar dan workshop yang melibatkan Pact-Indonesia dan WALHI di Bogor (Dalem, 2003:86). Workshop ini langsung mengarah pada ekowisata berbasis masyarakat dengan membawa tema -Community-based Ecotourism: Opportunity or Illusion?\|. 65 partisipan ikut serta mencakup LSM, para pembuat kebijakan, spesialis ekowisata, komunitas, dan operator tour (Lindberg et al, 1997:68). Dalam seminar ini, disimpulkan prinsip-prinsip ekowisata sebagai berikut (Sembiring et al, 2004:3): 
1) Perjalanan yang bertanggungjawab, dimana seluruh pihak yang terlibat dalam kegiatan ekowisata harus berupaya melakukan perlindungan alam atau setidak- tidaknya meminimalkan pengaruh negatif terhadap lingkungan alam dan budaya di lokasi objek ekowisata.

2) Lokasi ekowisata merupakan wilayah yang alami atau wilayah yang dikelola dengan mengacu kepada kaidah alam atau wilayah yang dikelola dengan kaidah alam. Kawasan yang dikelola mengacu kepada kaidah alam mencakup kawasan konservasi hutan dan kawasan non konservasi. Kawasan konservasi hutan terdiri dari taman nasional, taman wisata alam, taman hutan rakyat, dan cagar alam, sementara kawasan non konservasi adalah hutan adat. Wilayah yang dikelola dengan kaidah alam mencakup hutan wanagama, hutan produksi, taman hutan raya dan cagar budaya.

3) Tujuan perjalanan ke objek ekowisata adalah untuk menikmati pesona alam, mendapatkan pengetahuan, dan meningkatkatkan pemahaman berbagai fenomena alam dan budaya.

4) Semua pihak harus mendukung konservasi alam dan budaya dengan tindakan nyata baik secara moral maupun materil. Dana yang diperoleh dari kegiatan ekowisata harus digunakan untuk kelestarian alam, memberikan penghasilan kepada pelaku ekowisata, dan memdukung pertumbuhan kegiatan dan usaha bagi masyarakat sekitarnya.

5) Peran masyarakat di sekitar lokasi ekowisata harus ditingkatkan dalam penetapan perencanaan, pembangunan dan pengoperasiannya, agar dapat meningkatkan kesejahteraan mereka.

Setahun kemudian, Masyarakat Ekowisata Indonesia (MEI) dibentuk lewat Deklarasi Ekowisata Bali. Selain itu, sebuah jaringan ekowisata Indonesia (Indecon) dibentuk untuk memfasilitasi jaringan antar aktor ekowisata di Indonesia. Sungguhpun demikian, masing- masing organisasi dan lembaga pemerintahan menggunakan definisi ekowisata yang berbeda. Sebelum MEI dibentuk, pemerintah lewat Peraturan Pemerintah No 18 tahun 1994 memandang kalau ekowisata semata aktivitas yang berhubungan dengan wisata alam (Tomomi, 2010:80). Berdasarkan peraturan ini, kementerian kehutanan tetap menyamakan antara wisata alam dengan ekowisata (Tomomi, 2010:80).

Definisi ekowisata yang lebih tepat datang dari Kementerian Lingkungan Hidup. Kementerian ini mendefinisikan ekowisata sebagai - wisata dalam bentuk perjalanan ke tempat-tempat di alam terbuka yang relatif belum terjamah atau tercemar dengan tujuan khusus untuk mempelajari, mengagumi, dan menikmati pemandangan dengan tumbuh- tumbuhan serta satwa liarnya (Termasuk potensi kawasan berupa ekosistem, keadaan iklim, fenomena alam, kekhasan jenis tumbuhan dan satwa luar) juga semua manifestasi kebudayaan yang ada (Termasuk tatanan lingkungan sosial budaya), baik dari masa lampau maupun masa kini di tempat-tempat tersebut dengan tujuan untuk melestarikan lingkungan dan meningkatkan kesejahteraan masyarakat setempat\| (Sembiring et al, 2004:2-3). Begitu pula, kementerian pariwisata memiliki definisi yang lebih ramping namun telah cukup tepat dibandingkan dengan kementerian kehutanan sebagai - suatu konsep pengembangan pariwisata berkelanjutan yang bertujuan untuk mendukung upaya-upaya pelestarian lingkungan (alam dan budaya) dan meningkatkan partisipasi masyarakat dalam pengelolaan yang konservatif, sehingga memberikan manfaat ekonomi kepada masyarakat setempat\| (Sembiring et al, 2004:2). 


\section{Konsep Nilai}

Sesuatu yang menyaring persepsi ke dalam perilaku disebut sebagai nilai. Nilai mengandung sebuah skala yang membuat suatu perbuatan atau benda dipandang baik atau buruk. Nilai ini kemudian memandu hidup seseorang dalam sejumlah prinsip.

Ada empat kelompok nilai yang dimiliki oleh seseorang. Empat kelompok nilai ini adalah nilai instrumental, nilai eudaemonik, nilai moral, dan nilai intrinsik mutlak (Broring dan Wiegleb, 2005:528). Empat kategori nilai tersebut dapat dipersempit menjadi hanya dua kategori nilai yaitu nilai instrumental dan nilai intrinsik. Sheng tidak setuju kalau ada nilai instrumental dan non-instrumental. Klasifikasi nilai ke dalam nilai instrumental dan non- instrumental (intrinsik) berangkat dari gagasan utilitarianisme Mill. Ada sejumlah alasan yang diajukan Sheng untuk menolak kategorisasi ini. Pertama, nilai memiliki definisi yang kurang baik sehingga tidak terdapat hubungan yang logis antara nilai intrinsik dan nilai non- material (Sheng, 1998:78). Nilai material seperti bunga dapat memiliki nilai intrinsik seperti indah, tetapi bagaimana dengan —kekayaan\| yang non-material? Apa nilai intrinsik dari kekayaan? Kedua, hubungan yang tidak jelas antara nilai instrumental dan intrinsik (Sheng, 1998:79), apakah nilai instrumental menjadi alat menuju nilai intrinsik (seperti harta menjadi alat menuju kekayaan) atau nilai intrinsik yang membawa pada nilai instrumental (seperti kekayaan menyebabkan seseorang menumpuk harta). Untuk mengatasi hal ini, Rokeach (1973 dalam Baker, 2002:233) membagi nilai ke dalam nilai instrumental dan nilai terminal. Nilai instrumental adalah nilai yang digunakan untuk mencapai nilai terminal. Nilai instrumental misalnya kejujuran, keberanian, dan kelapangan dada, sementara nilai terminal dapat berupa kebahagiaan, kenikmatan, dan ketenangan (Baker, 2002:233). Kahle et al (1986 dalam Baker, 2002:233) membentuk kategori ketiga yang tidak dapat membedakan apakah nilai ini termasuk terminal atau instrumental. Nilai ambigu ini mencakuplah harga diri, rasa berprestasi, rasa dihargai, keamanan, kehangatan persahabatan, rasa memiliki, kesenangan hidup, rasa gembira, dan rasa diri yang penuh (Baker, 2002:233). Begitu pula, Gutman (1982 dalam Baker, 2002:233) menolak pembagian nilai tersebut dengan menempatkan nilai sebagai sesuatu yang telah mencapai akhir dan tidak ada nilai yang menjadi alat untuk menjadi nilai lainnya.

Banyaknya pendapat mengenai klasifikasi nilai di atas menunjukkan sifat general dari nilai. Sifat general ini muncul karena sifatnya yang abstrak sehingga mengatasi situasi (Nordlund dan Garvill, 2002:744). Ia diasumsikan ada dibalik suatu perbuatan tetapi seperti apa dirinya itu membutuhkan banyak analisis dengan pijakan konseptual yang berbeda-beda. Akibatnya, untuk menjelaskan satu perbuatan dibutuhkan banyak nilai yang menyaring persepsi untuk menghasilkan perbuatan tersebut. Hal ini yang membuat studi kuantitatif terhadap hubungan antara nilai dan perilaku menjadi studi yang kompleks (De Groot et al, 2007:134) atau setidaknya, memberikan hubungan yang lemah secara statistik.

Dari teori di atas, kita melihat bahwa konsep nilai merupakan konsep yang penuh perdebatan di antara berbagai bidang ilmu terkait hakikat dari nilai sehingga kita dihadapkan pada pilihan mengenai kategori nilai mana yang paling benar untuk memahami konteks kebijakan ekowisata.

\section{Nilai Lingkungan}

Ada dua aliran ekstrim dalam filsafat yang menghubungkan manusia dan alam sekitarnya. Pertama, manusia dapat memandang dirinya sebagai bagian dari alam. Sebagai bagian maka hakikat hidup manusia adalah berasal di alam dan keberadaan sekat-sekat yang memisahkan manusia dengan alam seperti struktur bangunan atau benteng, harusnya 
ditiadakan. Manusia bebas memasuki alam karena itu adalah tempat tinggalnya. Manusia dapat dengan bebas pula mengambil manfaat dari alam sejauh ia membutuhkannya. Pandangan kedua melihat bahwa manusia terpisah dari alam. Sebagai pihak yang terpisah dari alam, manusia dapat memperlakukan alam sebagai alat eksternal di luar dirinya untuk dimanfaatkan demi kepentingan manusia.

Dari perspektif kapitalisme, pandangan pertama disebut sebagai ekosentrisme sementara pandangan kedua disebut sebagai antroposentrisme. Pandangan kedua lebih mungkin mengeksploitasi alam dalam bentuk upaya membangun ekonomi dan mengatasi alam (Grendstad et al, 2006:74). Pandangan antroposentrisme karenanya tidak diinginkan dari segi konservasi.

Dalam kondisi konservasi, pandangan yang terjadi adalah sebaliknya. Pandangan antroposentrisme akan membangun pagar-pagar pembatas peradaban dan alam sehingga memberikan label seperti taman nasional, cagar alam, atau kawasan konservasi. Langkah ini didasarkan pandangan kalau alam harus dipisahkan dari manusia sejauh mungkin agar manusia tidak merusak alam tersebut. Pandangan antroposentrisme menjelma menjadi konservasionisme. Sementara itu, dari pandangan ekosentrisme, langkah membangun batas ini tidak diinginkan karena sama saja memisahkan manusia dari hakikatnya. Kita dapat melihat hal ini pada bagaimana manusia menyatu dengan alam dalam taman nasional sebagai bagian dari masyarakat lokal. Pandangan ini, walau begitu, dapat berakibat pada eksploitasi yang lebih tinggi dibandingkan pandangan konservasionisme. Pandangan penyatuan alam dengan manusia dalam konteks konservasi ini disebut pandangan fundamentalisme. Sebaliknya, dalam konteks konservasi, justru ekosentrisme atau fundamentalisme ini tidak diinginkan karena fungsi utama dari kawasan konservasi adalah memisahkan alam dari manusia sehingga alam dapat berfungsi sebaik mungkin.

Dasar filosofis antroposentris-ekosentris dan konservasionis-fundamentalis tersebut membangun nilai-nilai lingkungan pada diri manusia. Nilai lingkungan yang dimaksud disini adalah nilai yang diberikan manusia terhadap hubungannya dengan lingkungan hidupnya (Zografos dan Allcroft, 2007). Banyak klasifikasi yang dibuat mengenai nilai apa saja yang mencakup nilai lingkungan. Menurut Stern dan Dietz (1994), ada tiga nilai manusia yang menjadi dasar bagi kepedulian terhadap lingkungan. Tiga nilai ini adalah nilai sosio- altruistik, nilai egoistik, dan nilai biosferik (Schwartz, 1977). Ketiga nilai berbeda dalam orientasinya (Siddiqui, 2014:309). Nilai sosio-altruistik berorientasi pada kelompok masyarakat, nilai egoistik berorientasi pada kepentingan pribadi, dan nilai biosferik berorientasi pada kepentingan ekosistem secara keseluruhan. Ke arah mana seseorang condong, menentukan bagaimana ia menilai suatu isu lingkungan.

Klasifikasi nilai lingkungan sebagai sebuah kontinum seperti digambarkan diatas terlihat sangat menyederhanakan masalah. Pada akhirnya setiap orang akan lebih mementingkan dirinya sendiri ketimbang alam, apalagi dalam keadaan terancam. Akan sangat sulit menemukan seseorang yang benar-benar biosentris dalam menghadapi lingkungan kecuali ia memiliki pengetahuan yang sangat mendalam mengenai lingkungan hidupnya, yang sulit dilakukan dalam masyarakat yang tenggelam dalam keseharian lepas dari kemenyatuan dengan alam.

Klasifikasi dalam teori nilai Sheng (1998) terlihat sangat manusiawi dengan menempatkan moral sebagai dasar klasifikasi. Walau begitu, teori ini juga terlalu manusiawi sehingga sulit menemukan tempat bagi nilai lingkungan untuk berada dalam klasifikasinya. 
Sebuah teori yaitu teori nilai Schwartz dapat memfasilitasi kekurangan ini. Teori ini cukup universal sehingga mengandung nilai lingkungan dalam kategorisasinya sekaligus nilai-nilai yang manusiawi. Selain itu, studi kuantitatif menunjukkan kalau setidaknya dua dari empat dimensi nilai Schwartz memang berhubungan dengan perilaku pro lingkungan (Steg and De Groot, 2012; Collins et al, 2007; Kalof et al, 1999; Thogersen and Olander, 2003; Stern, 2000; Hirsh, 2010).

\section{Teori Nilai Schwartz}

Teori Schwartz membangun model klasifikasi nilai berdasarkan empat kelompok yaitu selftranscendence, conservatism, self-enhancement, dan openness to change. Empat kelompok ini bersifat bipolar sehingga pada dasarnya dapat dikerucutkan kembali menjadi dua kelompok besar. Self-enhancement bertentangan dengan self-transcendence sementara openness to change bertentangan dengan conservatism. Dalam studi ini, bipolar pertama berkaitan dengan orientasi seseorang terhadap lingkungan. Dapat dibayangkan kalau nilai lingkungan tertanam di dalam bipolar ini, dimana ujung egoisme berada di dimensi self- enhancement sementara ujung biosferik berada di dimensi self-transcendence. Bipolar kedua yaitu pasangan conservatism vs openness to change berhubungan dengan sikap manusia terhadap perubahan.

Kita dapat membangun sebuah kombinasi yang memprediksi perilaku seorang aktor berdasarkan orientasi yang dimiliki bersama. Seseorang sangat mendukung ekowisata jika ia menganut nilai self-transcendence dan openness to change. Seseorang menjadi oportunis jika ia menganut nilai openness to change namun berada pada self-enhancement. Seorang penentang ekowisata akan berada pada dimensi conservatism. Alasan penentangan ini dapat berorientasi pada kekhawatiran kerusakan alam jika ia menganut nilai self-transcendence atau kekhawatiran akan kehilangan kekuatan politis atau ekonomis jika berada di dimensi self- enhancement. 


\section{Gambar 1.2 Teori Nilai Schwartz}

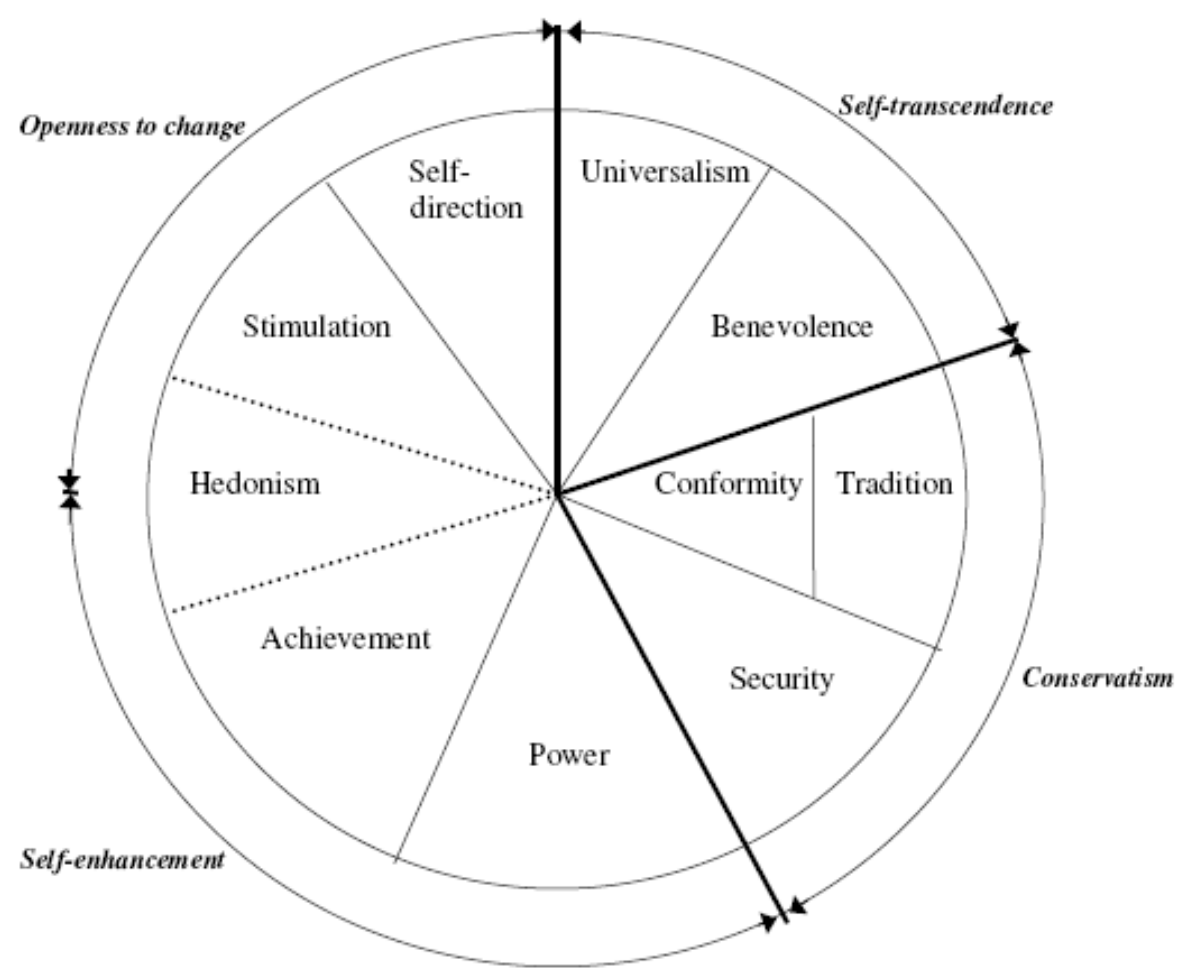

Sources: De Groot and Steg, 2012

\section{Perilaku}

Secara bilogis, perilaku didefinisikan sebagai — perubahan posisi bagian tubuh relatif terhadap bagian tubuh lainnya dan terhadap koordinat lingkungan\| (Feierman, 2009:73) yang memiliki - hasil atau keluaran nonstruktural dari satu bentuk atau struktur yang berinteraksi dengan bentuk atau struktur lainnya dalam ruang dan waktu dimana setidaknya satu dari kedua bentuk atau struktur tersebut adalah bagian dari individu yang berperilakull (Feierman, 2009:73).

Terdapat hubungan antara persepsi, nilai, dan perilaku manusia. Teori kognisi-afeksi- perilaku menyatakan adanya tahap kognisi yang memberikan manusia sebuah penilaian (afeksi) untuk melakukan suatu perbuatan (Holbrook, 2000:182). Lebih lanjut tahap penilaian harus menuju level konasi sebelum tiba pada perilaku (Huitt, 1999). Konasi adalah elemen motivasional dari suatu perbuatan yang memungkinkan afeksi dan kognisi layak untuk dilakukan (Lazarova, Westman, dan Shaffer, 2010:95). Karenanya, kerangka yang lebih lengkap adalah kognisiafeksi-motivasi-perilaku (Trevino, Weaver, dan Reynolds, 2006:960). Dalam bahasan sebelumnya, kita telah menyetujui bahwa kognisi atau persepsi merupakan bentuk perilaku sehingga hubungan yang terbentuk sebenarnya sebuah hubungan siklis dimana dari perilaku menghasilkan nilai dan nilai menghasilkan perilaku. Tentu saja, bukan nilai satu-satunya yang menentukan perilaku manusia, tetapi nilai menentukan persepsi manusia, sebagai salah satu bentuk perilaku.

Sejumlah faktor telah diajukan untuk menjelaskan perilaku rasional manusia. Faktor- faktor ini mencakup ancaman, rasa takut, efikasi respon, efikasi diri, kendala, manfaat, norma subjektif, sikap, niat, petunjuk pada perbuatan, dan reaktansi (World Bank, 2009:1). Walau 
begitu, semua faktor ini sebenarnya dapat hanya dikelompokkan dalam dua faktor yaitu faktor kontrol dan faktor diri (niat).

Beberapa studi menunjukkan pentingnya faktor diri pada perilaku manusia (Triandis, 1989; Kraut, 1973; Greenwald et al, 1987; Snyder, 1974). Hal ini wajar mengingat pada akhirnya, pelaku suatu perilaku adalah individu. Bahkan perilaku kolektif sekalipun dapat diurai sebagai perilaku individual anggota kelompok. Walau begitu, perilaku dapat muncul tanpa ada faktor diri dari pelaku, namun berdasarkan tekanan faktor kontrol. Seseorang dapat tidak ingin untuk memberi sesuatu pada orang lain, tetapi karena semua anggota kelompok melakukan hal tersebut, individu dapat melakukannya pula.

Dapat dikatakan pula bahwa niat merupakan faktor dari dalam individu sendiri, independen dari tekanan faktor kontrol. Teori perilaku terencana (Ajzen, 1991), walau begitu, tidak menerima pandangan ini karena menurut teori ini, niat salah satunya datang dari tekanan faktor kontrol lewat norma subjektif. Pemikiran alternatif yang memisahkan antara niat dan faktor kontrol lebih sejalan dengan teori nilai Schwartz yang membedakan antara keterbukaan terhadap perubahan dan self-enhancement dengan conservatism dan self- transcendence.

Bukan hanya teori Schwartz yang mendukung pengelompokkan faktor utama ini, sejumlah penemuan di bidang perilaku pro lingkungan menunjukkan kalau perilaku ini memiliki motif individual (niat) dan kontrol (prososial) (Robertson dan Barling, 2012:13). Gibson et al (2009:88) menyebutkan dua kelompok faktor yaitu kelompok lingkungan dan kelompok individual. Faktor lingkungan mencakup faktor kerja (desain kerja, struktur organisasi, kebijakan dan aturan, kepemimpinan, insentif dan sanksi, dan sumberdaya) dan faktor nonkerja (keluarga, ekonomi, peristirahatan, dan hobi). Faktor individual mencakup kecakapan, kemampuan, latar keluarga, kepribadian, persepsi, sikap, nilai, atribusi, kapasitas belajar, usia, ras, jenis kelamin, dan pengalaman. Teori ini, walau begitu, tampak hanya berlaku pada kebudayaan individualis atau setidaknya, kebudayaan urban atau industrialis. Hal ini terbukti dengan tidak adanya faktor budaya dalam kerangka perilaku ini. Walau begitu, kerangka ini termasuk kerangka penjelas faktor perilaku yang hampir lengkap dan menjadi lengkap jika diperluas pada level budaya atau informal. Dua faktor ini, kontrol dan niat dapat diartikan sebagai komponen yang menggabungkan penilaian dan motivasi dengan masukan dari kesadaran sebagai sebuah bentuk persepsi.

\section{Stakeholders}

Stakeholder merujuk pada - kelompok-kelompok yang vital bagi kelangsungan hidup dan keberhasilan dari organisasill (Yudarwati, 2011:26). Terdapat berbagai tipe keluasan yang menentukan tingkat seberapa vital kelompok tertentu dalam kelangsungan hidup organisasi (Yudarwati, 2011:26). Jika vitalitas disini diartikan hanya pada kepentingan ekonomi langsung (Mitchell, Agle, dan Wood, 1997:857), maka ia cukup mencakup kelompok seperti stockholders, pelanggan, dinas kunci di pemerintahan, karyawan, dan anggota rantai pasokan lainnya. Kelompok-kelompok ini ditentukan berdasarkan hubungan langsung organisasi dengan gaya-gaya eksternal yang berpengaruh pada aliran sumberdaya dan aliran nilai. Jika vitalitas disini diartikan lebih luas lagi dengan mencakup efek-efek tidak langsung dan mentolerir ketidakpastian yang lebih luas (Mitchell et al, 1997:857), para stakeholder dapat mencakup bukan hanya kelompok, namun juga individu, sejauh dapat berpengaruh atau dipengaruhi oleh kegiatan organisasi (Freeman, 2010:25). Ia bukan saja 
mencakup kelompok-kelompok sebelumnya, namun juga masyarakat lokal, berbagai kelompok serikat, dan bahkan masyarakat secara umum (Yudarwati, 2011:26). Singkatnya, stakeholder dapat diartikan sebagai siapapun atau kelompok apapun yang dipengaruhi atau mempengaruhi suatu masalah (Liburd, 2006:167). Dalam konteks pariwisata, keterlibatan stakeholder dalam proyek mempengaruhi pembangunan berkelanjutan karena adanya pertimbangan yang lebih besar mengenai keanekaragaman, baik dari segi sosial, lingkungan, politik, budaya, maupun ekonomi (Araujo dan Bramwell, 1999:356).

Reed (2008:5) mendaftarkan sejumlah manfaat dari keterlibatan stakeholder dalam proyek yang terbukti empiris oleh sejumlah penelitian. Manfaat ini antara lain:

1) Meningkatkan kualitas perencanaan manajemen jangka panjang (Brody, 2003).

2) Meningkatkan mutu kebijakan.

3) Mengurangi konflik antar stakeholder dan meningkatkan pengawasan implementasi kebijakan.

4) Membantu dalam memberikan informasi, gagasan, dan analisis untuk pengambilan keputusan yang lebih baik (Beierle, 2000).

Karena melibatkan banyak pihak, isu yang muncul dalam konteks multi-stakeholder adalah isu keadilan, informasi, dan partisipasi (Henisz dan Levitt, 2011; Dal Bo, Foster, dan Putterman, 2008). Hal ini menarik karena walaupun setiap pihak memiliki kepentingan, mereka sadar kalau kepentingan mereka tidak akan sepenuhnya terfasilitasi atau bahkan terhalangi (Arnstein, 1969; Jap, 2001; Krick, Monaghan, dan Sillanpaa, 2006). Karena kesadaran ini, maka mereka juga berharap pengorbanan yang mungkin terjadi tidak memunculkan oportunis yaitu ada pihak tertentu yang kepentingannya dipenuhi dengan mengorbankan diri mereka. Hal ini yang membuat isu keadilan menjadi penting. Terdapat alternatif lain selain persepsi keadilan yaitu sharing informasi (Henisz dan Levitt, 2011:16). Sejauh informasi dapat mengalir dengan baik dan kejujuran terjaga, para stakeholder dapat saling memahami berbagai pihak dan menyesuaikan diri.

Pentingnya stakeholder dan manajemennya di atas menunjukkan perlunya penelitian stakeholder dilakukan sebagai bagian dari perencanaan untuk pengelolaan. Penelitian stakeholder berupaya menjelaskan dan memprediksi bagaimana stakeholder merespon dan memberikan pengaruh pada lingkungannya (Marstein, 2003:24). Pada gilirannya, sebuah kerangka strategis dapat dibangun untuk menghasilkan kemitraan yang berhasil (Heninsz dan Levitt, 2011:17). Panduan umum yang digunakan untuk menghasilkan kemitraan positif mirip dengan strategi manajemen partisipatif. Keduanya bahkan dapat dipandang dapat dipertukarkan karena melibatkan stakeholder dalam pengambilan keputusan. Secara umum, upaya ini mencakup (1) workshop multi-stakeholder di awal proyek untuk membangun persetujuan bersama, yang kemudian dilanjutkan dengan follow up berkelanjutan, (2) pembangunan tujuantujuan yang jelas, (3) desain resolusi konflik yang mungkin terjadi, (4) melibatkan stakeholder dalam hirarki manajemen hingga level puncak, dan (5) penekanan pemecahan masalah multi stakeholder berorientasi hasil (Heninsz dan Levitt, 2011; Larson, 1997; Crane et al, 1999).

Dengan demikian, para stakeholder perlu untuk menekankan pentingnya hubungan dibangun untuk menghasilkan keluaran yang lebih besar (Hall, 1999:275). Teori-teori kolaborasi (Devine, Boyd, dan Boyle, 2010; Barringer dan Harrison, 2000) menyatakan bahwa suatu aktor perlu melakukan kolaborasi dengan berbagai alasan. Alasan-alasan ini antara lain kebutuhan, resiprositas, stabilitas, asimetri, efisiensi, dan legitimasi (Devine et al, 2010:202). 
Teori kolaborasi yang sejalan dengan teori nilai Schwartz adalah teori kolaborasi pilihan. Teori ini membagi tipe kolaborasi menjadi dua tipe yaitu tipe rasional dan tipe sosial (Lynn dan Hill, 2001:27). Dalam teori nilai Schwartz, kolaborasi tipe sosial sejalan dengan nilai-nilai konservatisme sementara kolaborasi tipe rasional sejalan nilai-nilai keterbukaan pada perubahan. Tipe rasional adalah kolaborasi yang didasarkan oleh kontrak dan cenderung bersifat eksternal, yaitu setiap partisipan lebih mengarah ke luar dari kolaborasi dengan menjaga jarak dengan partisipan lainnya. Kekuatan dari kolaborasi tipe ini terletak pada jumlah pihak yang berkolaborasi dan lebih sering dipandang sebagai bentuk koordinasi (Kaiser, 2011:6).

\section{KESIMPULAN}

Dari studi literatur di atas, kita ketahui bahwa Taman Nasional menghadapi masalah umum dalam kompromi antara konservasi dan ekonomi. Fungsi utama dari Taman Nasional sebagai wilayah konservasi berhadapan dengan keberadaan masyarakat asli di dalam Taman Nasional yang, sebagai manusia, tidak dapat diperlakukan sama seperti objek alam yang harus dilestarikan ataupun dibedakan sepenuhnya dengan diusir keluar dari tanah asalnya. Adanya paradoks ini membawa pada dua model utama manajemen taman nasional: model cetak biru/profesional dan model proses/partisipatif. Model proses lebih diutamakan karena memungkinkan sistem beradaptasi dengan baik lewat upaya pengakuan atas keanekaragaman perspektif maupun pilihan manajerial ketimbang standarisasi baku yang pasti. Selain itu, model proses terarah pada upaya pemberdayaan masyarakat desa selain dalam upaya konservasi. Model proses bersifat partisipatif dan karenanya, melibatkan banyak aktor dalam upaya manajerial taman nasional.

Konsep Ekowisata sebagai salah satu wacana yang umum dialamatkan pada manajemen taman nasional menekankan kembali pentingnya aspek manusia dalam taman nasional walaupun lebih diarahkan pada masyarakat sebagai sasaran, ketimbang partisipan. Manajemen berbasis proses pada taman nasional kemudian memberikan kerangka bagaimana seharusnya wacana ini diinisiasi dan dikelola bersama setiap stakeholder, yaitu lewat model partisipasi.

Walaupun demikian, setiap stakeholder memiliki persepsi berbeda mengenai suatu masalah, termasuk masalah ekowisata. Persepsi ini mengandung komponen kognitif dan komponen emosional. Suatu isu ekowisata dapat saja sangat rasional bagi satu individu, namun menjadi sangat emosional bagi individu lainnya. Kedua komponen harus dialamatkan untuk menghasilkan persepsi yang positif mengenai penerapan ekowisata.

Akan tetapi, ada sifat subjektif dari persepsi yang kemudian memperumit upaya pembangunan persepsi positif yang dapat diterima oleh semua individu aktor yang terlibat dalam pengelolaan ekowisata. Strategi yang terarah adalah dengan melihat pada nilai-nilai yang dianut oleh para aktor dan memprediksi bagaimana para aktor menggunakan nilai ini untuk membangun persepsi kognitif dan emosional mengenai pesan ekowisata yang dibangun bersama.

Untuk menganalisis nilai tersebut, Schwartz menawarkan teori nilai yang dapat digunakan pada kelompok nilai yang berkontestansi dalam manajemen taman nasional, yaitu antara kepentingan konservasi dan kepentingan ekonomi.

Pada akhirnya, nilai-nilai kehidupan tidak dapat semata tertranslasi menjadi perilaku. Dalam konteks hubungan antar manusia, apalagi dalam iklim multistakeholder, kolaborasi 
memegang peranan yang sangat penting. Upaya ekowisata akan gagal jika tidak semua pihak memberikan dukungan bagi pengelolaan yang berkelanjutan. Suatu pemetaan jaringan aktor dan nilai-nilai yang dianutnya akan memberikan gambaran masa depan taman Nasional dalam upaya ekowisata yang dijalankannya.

$* * * * * *$

\section{DAFTAR PUSTAKA}

[Web page] official website of forest department sarawak Retrieved, 2014, Retrieved from http://www.forestry.sarawak.gov.my/page.php?id=148\&menu_id=0\&sub_id=90

45 taman nasional di indonesia Retrieved, 2014, Retrieved from http://www.dephut.go.id/uploads/INFORMASI/TN INDO-ENGLISH/tn_index.htm

Ajzen, I. (1991). The theory of planned behavior. Organizational Behavior and Human Decision Processes, 50(2), 179-211.

Ap, J., \& Pang, D. (2002). Community perceptions of eco-tourism. Annals School of Hotel \& Tourism Management.e Hong Kong Polytechnic University.Hong Kong SAR, CHINA,

Araujo, L. M. d., \& Bramwell, B. (1999). Stakeholder assessment and collaborative tourism planning: The case of brazil's costa dourada project. Journal of Sustainable Tourism, 7(3-4), 356-378.

Arnstein, S. R. (1969). A ladder of citizen participation. Journal of the American Institute of Planners, 35(4), 216-224.

Baker, S. (2002). Laddering: Making sense of meaning. Essential Skills for Management Research, , 226-253.

Barker, A. (2009). Wind power and ecotourism. (Doctor, University of Oslo).

Beierle, T. C. (2000). The quality of stakeholder-based decisions: Lessons from the case study record. Resources for the Future, Washington,

Blamey, R. K. (2001). Principles of ecotourism. The Encyclopedia of Ecotourism, 2001, 5- 22.

Brody, S. D. (2003). Measuring the effects of stakeholder participation on the quality of local plans based on the principles of collaborative ecosystem management. Journal of Planning Education and Research, 22(4), 407-419.

Bröring, U., \& Wiegleb, G. (2005). Assessing biodiversity in SEA. Implementing strategic environmental assessment (pp. 523-538) Springer. 
Buchsbaum, B. D. (2004). Ecotourism and sustainable development in costa rica. (Doctor, Virginia Polytechnic Institute and State University).

Chambers, R., \& Pretty, J. (1993). Towards a learning paradigm: New professionalism and institutions for agriculture.

Chambliss, K., Slotkin, M. H., \& Vamosi, A. R. (2007). Sustainability of avian ecotourism. Paper presented at the An International Forum on Sustainability, 4th, Melbourne, Florida.

Chi, C. (2007). The ideas and ideals of first nations and their application in taiwan: A critical evaluation. Taiwan International Studies Quarterly, 3(2), 1-22.

Cole, D. N. (1983). Assessing and monitoring backcountry trail conditions. Ogden, Utah: Ogden, UT : U.S. Dept. of Agriculture, Forest Service, Intermountain Forest and Range Experiment Station.

Collins, C. M., Steg, L., \& Koning, M. A. (2007). Customers' values, beliefs on sustainable corporate performance, and buying behavior. Psychology \& Marketing, 24(6), 555-577.

Crane, T. G., Felder, J. P., Thompson, P. J., Thompson, M. G., \& Sanders, S. R. (1999). Partnering measures. Journal of Management in Engineering, 15(2), 37-42.

Dal Bó, P., Foster, A., \& Putterman, L. (2008). Institutions and behavior: Experimental evidence on the effects of democracy. American Economic Review, 100, 2205-2229.

Dam, S. (2013). Issues of sustainable ecotourism development in sikkim: An analysis. Sajth, $6(2)$

Dawson, C. P. (2008). Ecotourism and nature-based tourism: One end of the tourism opportunity spectrum? In S. F. McCool, \& R. N. Moisey (Eds.), Tourism, recreation and sustainability; linking culture and the environment (2nd ed., pp. 38). Montana, USA: CABI.

De Groot, J., Steg, L., \& Dicke, M. (2007). Morality and reducing car use: Testing the norm activation model of prosocial behavior. Transportation Research Trends, NOVA Publishers,

Deddy, K. (2006). Chapter five community mapping, tenurial rights and conflict resolution in kalimantan. State, Communities and Forests in Contemporary Borneo, , 89.

Denman, R. (2001). Guidelines for community-based ecotourism development. WWF International Gland, Switzerland.

Devine, A., Boyd, S., \& Boyle, E. (2010). Unravelling the complexities of inter- organisational relationships within the sports tourism policy arena on the island of ireland. Contemporary Issues in Irish and Global Tourism and Hospitality, , 200. 
Diamantis, D. (1999). The concept of ecotourism: Evolution and trends. Current Issues in Tourism, 2(2-3), 93-122.

Eghenter, C. (2006). Social, environmental and legal dimensions of adat as an instrument of conservation in east kalimantan. State, Communities and Forests in Contemporary Borneo, , 163.

Fay, C., Sirait, M., \& Kusworo, A. (2000). Getting the boundaries right: Indonesia's urgent need to redefine its forest estate. World Agroforestry Center, Bogor, Indonesia,

Feierman, J. R. (2009). The biology of religious behavior: The evolutionary origins of faith and religion. ABC-CLIO.

Fennell, D. A. (2008). Ecotourism (3rd ed.). London: Routledge.

FEWMD (2009): Preparatory Study on Integrated Project for Sustainable Development of forest Resources in Sikkim, Final Report, Nov, Govt. of Sikkim, 115.

Forestry, P. J. L. K. 2.H. L. (2010). Statistik direktorat pemanfaatan jasa lingkungan kawasan konservasi dan hutan lindung 2010. Bogor, Indonesia: Indonesia Ministry of Forestry.

Freeman, R. E. (2010). Strategic management: A stakeholder approach. Cambridge University Press.

Gibson, J. L., Ivancevich, J. M., \& Donnelly, J. H. (2009). Organizations: Behavior, structure, processes (14th ed.) McGraw-Hill, Irwin Homewood, IL.

Greenwald, A. G., Carnot, C. G., Beach, R., \& Young, B. (1987). Increasing voting behavior by asking people if they expect to vote. Journal of Applied Psychology, 72(2), 315.

Grendstad, G., Selle, P., Strømsnes, K., \& Bortne, Ø. (2006). Unique environmentalism, A comparative perspective Springer Science+Business Media, LLC.

Hall, C. M. (1999). Rethinking collaboration and partnership: A public policy perspective. Journal of Sustainable Tourism, 7(3-4), 274-289.

HENISZ, W. J., \& LEVITT, R. E. (2011). Regulative, normative and cognitive institutional supports for relational contracting: Toward a contingent project governance framework. Unpublished manuscript.

Higham, J. (2007). Critical issues in ecotourism. Routledge.

Hirsh, J. B. (2010). Personality and environmental concern. Journal of Environmental Psychology, 30(2), 245-248.

Holbrook, M. B. (2000). The millennial consumer in the texts of our times: Experience and entertainment. Journal of Macromarketing, 20(2), 178-192. 
Huitt, W.Conation: An important factor of mind Retrieved, 2014, Retrieved from http://www.edpsycinteractive.org/topics/conation/conation.html

IUCN, C. (International Union for Conservation of Nature and Natural Resources, 1976). Twelfth general assembly: Kinshasa, zaire. IUCN Publications New Series,

Jacob, S., \& Luloff, A. (1995). Exploring the meaning of rural through cognitive Maps1. Rural Sociology, 60(2), 260-273.

Jap, S. D. (2001). -Pie sharing\| in complex collaboration contexts. Journal of Marketing Research, 38(1), 86-99.

Kaiser, F. (2011). Interagency collaborative arrangements and activities: Types, rationales, considerations, congressional research service. (No. 7-5700).Congressional Research Service.

Kalof, L., Dietz, T., Stern, P. C., \& Guagnano, G. A. (1999). Social psychological and structural influences on vegetarian beliefs. Rural Sociology, 64(3), 500-511.

Kraut, R. E. (1973). Effects of social labeling on giving to charity. Journal of Experimental Social Psychology, 9(6), 551-562.

Krick, T., Forstater, M., Monaghan, P., \& Sillanpää, M. (2005). The stakeholder engagement manual volume 2: The practitioners handbook on stakeholder engagement. Account Ability, the United Nations Environment Programme, and Stakeholder Research Associates,

Lankford, S. V., Scholl, K., Pfister, R., Lankford, J., Williams, A., \& Bricker, K. (2004). Cognitive mapping: An application for trail management. Paper presented at the Proceedings of the 2004 Northeastern Recreation Research Symposium, 378-384.

Larson, E. (1997). Partnering on construction projects: A study of the relationship between partnering activities and project success. Engineering Management, IEEE Transactions on, 44(2), 188-195.

Lazarova, M., Westman, M., \& Shaffer, M. A. (2010). Elucidating the positive side of the workfamily interface on international assignments: A model of expatriate work and family performance. Academy of Management Review, 35(1), 93-117.

Liburd, J. J. (2006). Sustainable tourism and national park development in st. lucia. Advances in Tourism Research: Tourism and Social Identities: Global Frameworks and Local Realities, , 155-176.

Liddle, M., \& Greig-Smith, P. (1975). A survey of tracks and paths in a sand dune ecosystem I. soils. Journal of Applied Ecology, , 893-908.

Lindberg, K., \& Sproule, K. (1998). Ecotourism in the asia-pacific region: Issues and outlook FAO, Forestry Policy and Planning Division. 
Ludwig, D., Hilborn, R., \& Walters, C. (1993). Uncertainty, resource exploitation, and conservation: Lessons from history. Science(Washington), 260(5104), 17.

Lynn, L. E., \& Hill, C. J. (2001). Producing human services: Why do agencies collaborate?. Citeseer.

Marion, J. L., \& Leung, Y. (2001). Trail resource impacts and an examination of alternative assessment techniques. Journal of Park \& Recreation Administration, 19(3)

Markel, C., \& Clark, D. (2012). Developing policy alternatives for the management of wood bison (bison bison athabascae) in kluane national park and reserve of canada. Northern Review, (36), 53-75.

Marstein, E. (2003). The influence of stakeholder groups on organizational decision-making in public hospitals. (Doctor, Norwegian School of Management BI). Series of Dissertations, 2

Masozera, M. K., Alavalapati, J. R., Jacobson, S. K., \& Shrestha, R. K. (2006). Assessing the suitability of community-based management for the nyungwe forest reserve, rwanda. Forest Policy and Economics, 8(2), 206-216.

McGahey, S. (2012). The ethics, obligations, and stakeholders of ecotourism marketing. Intelektinè Ekonomika, (6 (2), 75-88.

Miller, K. L. (2008). Evaluating the design and management of community-based ecotourism projects in guatemala. (Master, The University of Montana).

Ministry of Environment. (2006). Third national report to the convention on biological diversity. (). Indonesia:

Mitchell, R. K., Agle, B. R., \& Wood, D. J. (1997). Toward a theory of stakeholder identification and salience: Defining the principle of who and what really counts. Academy of Management Review, 22(4), 853-886.

Nordlund, A. M., \& Garvill, J. (2002). Value structures behind proenvironmental behavior. Environment and Behavior, 34(6), 740-756.

Nuva, R., Shamsudin, M. N., Radam, A., \& Shuib, A. (2009). Willingness to pay towards the conservation of ecotourism resources at gunung gede pangrango national park, west java, indonesia. Journal of Sustainable Development, 2(2)

Obenaus, S. (2005). Ecotourism - sustainable tourism in national parks and protected areas: A case study of banff national park in canada and national park gesäuse in austria - a comparison. (Unpublished

Pelser, A., Redelinghuys, N., \& Velelo, N. (2011). People, parks and poverty: Integrated conservation and development initiatives in the free state province of south africa. Biological Diversity and Sustainable Resources use, , 35-62. 
Pimbert, M. P., \& Pretty, J. N. (1997). Parks, people and professionals: Putting participation into protected area management. Social Change and Conservation, , 297-330.

Piskorskaya, N., Kristanti, Y., Lissandhi, A. N., \& Ratri, S. D. (2012). Knowledge dissemination. Refining REDD in indonesia: Policy recommendations for increasing effectiveness, efficiency, and equity (pp. 90-119)

Poirier, R., \& Ostergren, D. (2002). Evicting people from nature: Indigenous land rights and national parks in australia, russia, and the united states. Nat.Resources J., 42, 331.

Prato, T. (2006). Adaptive management of national park ecosystems. Paper presented at the The George Wright Forum, , 23(1) 72-86.

Reed, M. S. (2008). Stakeholder participation for environmental management: A literature review. Biological Conservation, 141(10), 2417-2431.

Robertson, J. L., \& Barling, J. (2013). Greening organizations through leaders' influence on employees' pro-environmental behaviors. Journal of Organizational Behavior, 34(2), 176-194.

Ross, S., \& Wall, G. (1999). Ecotourism: Towards congruence between theory and practice. Tourism Management, 20, 123.

Scheyvens, R. (1999). Ecotourism and the empowerment of local communities. Tourism Management, 20(2), 245-249.

Schwartz, S. H. (1992). Universals in the content and structure of values: Theoretical advances and empirical tests in 20 countries. Advances in Experimental Social Psychology, 25(1), 1-65.

Sembiring, I., Hasnudi, Irfan, \& Umar, S. (2004). Survei potensi ekowisata di kabupaten dairi. ().Universitas Sumatera Utara.

Sembiring, S. N. (2005). Autonomy and the future of Protected/Conservation area management in indonesia: A legal analysis. Conservation for/by Whom? Social Controversies \& Cultural Contestations regarding National Parks and Reserves in the

-malay Archipelago,

Sheng, C. L. (1998). A utilitarian general theory of value. Rodopi.

Siddiqui, R. N. (2014). The Environment-Behaviour Link: Challenges for Policy Makers, In Psychology, Development, and Social Policy in India. Eds: R C Tripathi dan Y. Sinha. New York: Springer, 297.

Sirakaya, E., Sasidharan, V., \& Sönmez, S. (1999). Redefining ecotourism: The need for a supply-side view. Journal of Travel Research, 38(2), 168-172.

Snyder, M. (1974). Self-monitoring of expressive behavior. Journal of Personality and Social Psychology, 30(4), 526. 
Steg, Linda and de Groot, Judith I.M. (2012). Environmental values. In S. D. Clayton (Ed.), The oxford handbook of environmental and conservation psychology () Oxford University Press.

Stern, P. C. (2000). New environmental theories: Toward a coherent theory of environmentally significant behavior. Journal of Social Issues, 56(3), 407-424.

Stern, P. C., \& Dietz, T. (1994). The value basis of environmental concern. Journal of Social Issues, 50(3), 65-84.

Thøgersen, J., \& Ölander, F. (2003). Spillover of environment-friendly consumer behaviour. Journal of Environmental Psychology, 23(3), 225-236.

Timko, J. A., \& Innes, J. L. (2009). Evaluating ecological integrity in national parks: Case studies from canada and south africa. Biological Conservation, 142(3), 676-688.

Tisen, O. B. (2004). Conservation and tourism: A case study of longhouse communities in and adjacent to batang ai national park, sarawak, malaysia. (Master, Lincoln University).

Tomomi, I. (2010). Ecotourism in bali: Backgrounds, present conditions and challenges. (Unpublished Doctor). Graduate School of International Relations, Ritsumeikan University,

Treviño, L. K., Weaver, G. R., \& Reynolds, S. J. (2006). Behavioral ethics in organizations: A review. Journal of Management, 32(6), 951-990.

Triandis, H. C. (1989). The self and social behavior in differing cultural contexts. Psychological Review, 96(3), 506.

UNESCAP. (1995). Guidelines on environmentally sound development of coastal tourism. New York: United Nations.

Upton, C., Ladle, R., Hulme, D., Jiang, T., Brockington, D., \& Adams, W. M. (2008). Are poverty and protected area establishment linked at a national scale? Oryx, 42(01), 19- 25.

Van Beukering, P. J., Cesar, H. S., \& Janssen, M. A. (2003). Economic valuation of the leuser national park on sumatra, indonesia. Ecological Economics, 44(1), 43-62.

Vernhes, J. R., \& Bridgewater, P. (2008). Biosphere reserves. In Chape S., Spalding M. \& Jenkins M.D. (Eds.), The world's protected areas (pp. 28-32). Berkeley, USA.: Prepared by the UNEP World Conservation Monitoring Centre. University of California Press.

Weihrich, H. (1982). The TOWS matrix - A tool for situational analysis. Long Range Planning, 15(2), 54-66. 
World Bank. (2011). Theories of behavior change. Communication for Governance and Accountability Program,

World ecotourism summit-final report, quebec city, canada. (2002). (). Madrid, Spain: The World Tourism Organization and the United Nations Environment Programme.

Young, K. (2012). Laws. Refining REDD in indonesia: Policy recommendations for increasing effectiveness, efficiency, and equity (pp. 25-30)

Yudarwati, G. A. (2011). The enactment of corporate social responsibility and public relations practices: Case studies from the indonesian mining industry. (Doctor, RMIT University Melbourne).

Zografos, C., \& Allcroft, D. (2007). The environmental values of potential ecotourists: A segmentation study. Journal of Sustainable Tourism, 15(1), 44-66. 